\title{
Effect of citric acid and the hemihydrate amount on the properties of a calcium sulphoaluminate cement
}

\author{
G. Velazco $\bowtie$, J.M. Almanza, D.A. Cortés, J.C. Escobedo, J.I. Escalante-Garcia \\ Cinvestav Saltillo (Coah, México) \\ \gerardo.velazco@cinvestav.edu.mx
}

\author{
Received 16 May 2013 \\ Accepted 29 July 2013 \\ Available on line 1 D ecember 2014
}

\begin{abstract}
The influence of citric acid on the hydration and strength development of a calcium sulphoaluminate cement was investigated. Cement pastes were prepared by mixing calcium sulphoaluminate $\left(\mathrm{C}_{4} \mathrm{~A}_{3} \hat{\mathrm{S}}\right)$ with 15,20 and $25 \mathrm{wt} \%$ of hemihydrate $\left(\mathrm{CS}^{\mathrm{S}} \mathrm{H}_{0.5}\right)$. Citric acid was added as a retarder at 0 and $0.5 \mathrm{wt} \%$. The samples were cured at $20^{\circ} \mathrm{C}$ for periods of time from 1 to 28 days to evaluate their compressive strength and to characterize the hydration products by scanning electron microscopy and X-ray diffraction. Calorimetric curves showed that the retarding agent considerably decreases the heat release rate and the quantity of total heat released. The main product after the curing was ettringite $\left(\mathrm{C}_{6} \mathrm{AS}_{3} \mathrm{H}_{32}\right)$. The morphology of this phase consisted of long and thin needles growing radially on the cement grains. Samples with $15 \mathrm{wt} \%$ of hemihydrate and $0.5 \mathrm{wt} \%$ of citric acid developed the highest compressive strength $(70 \mathrm{MPa})$ at 28 days of curing.
\end{abstract}

KEYWORDS: Calorimetry; Ettringite; Sulphoaluminate; Citric acid

Citation / Citar como: Velazco, G.; Almanza, J.M.; Cortés, D.A.; Escobedo, J.C.; Escalante-Garcia, J.I. (2014) Effect of citric acid and the hemihydrate amount on the properties of a calcium sulphoaluminate cement. Mater. Construcc. 64 [316], e036 http://dx.doi.org/10.3989/mc.2014.03513.

RESUMEN: Efecto de la adición de ácido cítrico y la cantidad de yeso sobre las propiedades del cemento de sulfoaluminato de calcio. Se investigó el efecto del ácido cítrico sobre la hidratación y propiedades mecánicas de un cemento de sulfoaluminato de calcio. $\mathrm{El} \mathrm{C}_{4} \mathrm{~A}_{3} \hat{\mathrm{S}}$ se mezcló con 15,20 y $25 \%$ e.p. de hemihidrato $\left(\mathrm{CS}^{\mathrm{S}} \mathrm{H}_{0.5}\right)$. Se agregó ácido cítrico como retardante en 0 y $0.5 \%$ e.p. Las muestras fueron curadas a $20{ }^{\circ} \mathrm{C}$ por periodos de 1 a 28 días para realizar mediciones de resistencia a la compresión y caracterizar los productos de hidratación mediante microscopía electrónica de barrido y difracción de rayos X. Las curvas de calorimetría mostraron ue el ácido cítrico disminuye la velocidad de liberación de calor y la cantidad de calor liberado durante la hidratación. La resistencia a la compresión alcanzó un máximo de $70 \mathrm{MPa}$ en muestras con 15\% e.p. de hemihidrato y $0,5 \%$ e.p de ácido cítrico. Los resultados muestran a la etringita $\left(\mathrm{C}_{6} \mathrm{AS}_{3} \mathrm{H}_{32}\right)$ como principal producto de hidratación. Se observa a esta fase con morfología acicular creciendo sobre las partículas de cemento.

PALABRAS CLAVE: Calorimetría; Etringita; Sulfoaluminato; Ácido cítrico

Copyright: (C) 2014 CSIC. This is an open-access article distributed under the terms of the Creative Commons Attribution-Non Commercial (by-nc) Spain 3.0 License.

\section{INTRODUCTION}

The need to reduce energy consumption and emissions of carbon dioxide into the atmosphere during the manufacture of Portland cement has been a determining factor in the development of alternative cementitious materials with properties that can replace Portland cement. The calcium sulphoaluminate based cements (CSA) have drawn attention recently because during its production, the atmospheric $\mathrm{CO}_{2}$ emissions are lower compared with those of portland cement PC (1-3). It has been 
estimated that the total of $\mathrm{CO}_{2}$ emissions associated with $1 \mathrm{~T}$ of $\mathrm{PC}$ are $0.815 \mathrm{~T}$; from this, $0.425 \mathrm{~T}$ are originated from the decomposition of the raw materials and $0.39 \mathrm{~T}$ from the combustion of fossil fuels, including those required to generate the electricity for the plant operation (4). The calcium sulphoaluminate cements consist mainly in the phase Ye'elemite, also called Klein's salt or tetracalcium trialuminate sulphate $\left(\mathrm{C}_{4} \mathrm{~A}_{3} \hat{\mathrm{S}}\right)$ (5). Other advantages of these cements over PC are: lower power consumption, higher early strength development, excellent durability in saline environments and good protection to steel reinforcement (6). The calcium sulphoaluminate $\left(\mathrm{C}_{4} \mathrm{~A}_{3} \hat{\mathrm{S}}\right)$ can be synthesized by calcining stoichiometric proportions of calcium carbonate $\left(\mathrm{CaCO}_{3}\right)$, aluminium hydroxide $\left(\mathrm{Al}(\mathrm{OH})_{3}\right)$ and gypsum $\left(\mathrm{CaSO}_{4} \cdot 2 \mathrm{H}_{2} \mathrm{O}\right)$ in a furnace at temperatures ranging from 1250 to $1300{ }^{\circ} \mathrm{C}$ for 3 hours (7). F. Puertas et al. (8) studied the thermal behaviour of the calcium sulphoaluminate at a $1300-1500{ }^{\circ} \mathrm{C}$ and maintaining the final temperature for 21 hours; they found that as a consequence of the thermal treatment, the $\mathrm{C}_{4} \mathrm{~A}_{3} \hat{\mathrm{S}}$ starts to decompose at $1300{ }^{\circ} \mathrm{C}$ by eliminating $\mathrm{SO}_{2}$ and obtaining $\mathrm{CA}$ and $\mathrm{CaO}$, which produced $\mathrm{C}_{12} \mathrm{~A}_{7}$ by solid state reaction. Other materials used in calcium sulphoaluminate production are: limestone, bauxite, aluminium-rich clay and gypsum. As a source of alumina, "red mud", a largely unwanted by-product of the Bayer process for alumina purification, has also been used (9). Besides gypsum, fluorgypsum and anhydrite are also used as a source of calcium sulphate (10).

The early hydration of the CSA cements is mainly governed by the amount and reactivity of the added calcium sulphate $(11,12)$; the main reaction products are ettringite $\left(\mathrm{C}_{6} \mathrm{AS}_{3} \mathrm{H}_{32}\right)$ and monosulphate $\left(\mathrm{C}_{4} \mathrm{AS} \mathrm{SH}_{12}\right)$ (13). Ettringite is formed by one of two mechanisms; during the setting stage of the pastes by a through-solution mechanism and later after the paste has hardened forming crystals with preferred orientation on the surface of an unhydrated aluminium phase takes place (14).

The degree of hydration of the cement is greatly influenced by the presence of organic admixtures. The formation of insoluble hydration products retards the subsequent hydration of the cement compounds by forming a barrier to water transport. The solubility of the anhydrous cement phases and the precipitation of hydration products are important factors in the setting of cement pastes. It has been found that organic retarders act by forming insoluble complexes when in contact with the strongly alkaline environment of a cement paste (15). Carboxylic acids (citric, tartaric, gluconic, malic, etc.) and their salts are commonly used as retarding admixtures as these delay the setting time of concrete without adversely affecting subsequent strength development, whilst permitting a substantial reduction in the water/cement ratio
(16). Tinnea and Young (17) and Singh et al. (18) showed that citric acid has a retarding effect in the system $\mathrm{C}_{3} \mathrm{~A}$-gypsum-portlandite-water. Möschner et al. (19) investigated the influence of citric acid on the hydration of Portland cement and pointed that the citric acid retards the cement hydration not by complex formation, but slowing down the dissolution of the clinker grains. Due to the rapid setting of CSA cements, the use of retarder admixtures is necessary in order to increase their workability. This paper presents an investigation on the effects of a citric acid admixture and the amount of hemihydrate on the strength development, microstructures and the hydration during the early curing stages of CSA cements.

\section{EXPERIMENTAL}

Calcium sulphoaluminate $\left(\mathrm{C}_{4} \mathrm{~A}_{3} \hat{\mathrm{S}}\right)$ was synthesized at $1350{ }^{\circ} \mathrm{C}$ for $4 \mathrm{~h}$ from a stoichiometric mixture of commercial materials $\mathrm{CaCO}_{3}$ (OMYA S.A), $\mathrm{CaSO}_{4} \cdot 1 / 2 \mathrm{H}_{2} \mathrm{O}$ (Yesera Monterrey S.A.) and $\mathrm{Al}(\mathrm{OH})_{3}$ (Possehl S.A.). The resulting product was dry ball milled in order to obtain a Blaine specific surface area within $350-400 \mathrm{~m}^{2} / \mathrm{kg}$ according to ASTM C-204 (20). The proportion of each compound was determined according to the following reaction:

$$
\begin{aligned}
& 3 \mathrm{CaCO}_{3}+6 \mathrm{Al}(\mathrm{OH})_{3}+\mathrm{CaSO}_{4} \cdot 1 / 2 \mathrm{H}_{2} \mathrm{O} \rightarrow \\
& 3 \mathrm{CaO} \cdot 3 \mathrm{Al}_{2} \mathrm{O}_{3} \cdot \mathrm{CaSO}_{4}+91 / 2 \mathrm{H}_{2} \mathrm{O}+3 \mathrm{CO}_{2}
\end{aligned}
$$

Cement samples of different compositions were prepared by adding 15,20 and $25 \mathrm{wt} \%$ of $\mathrm{CaSO}_{4} \cdot 1 / 2 \mathrm{H}_{2} \mathrm{O}$ to the $\mathrm{C}_{4} \mathrm{~A}_{3} \hat{\mathrm{S}}$. Some of the cements were admixed with $0.5 \%$ citric acid as a retarder. Table 1 shows the composition of the samples prepared.

Pastes prepared with distilled water using water/ cement ratios $(\mathrm{w} / \mathrm{c})$ of 0.4 and 0.5 . These were cast in Nylamid cubic moulds of $2.54 \mathrm{~cm}$ per side. Curing was carried out by immersing the cubes in water at a constant temperature of $20{ }^{\circ} \mathrm{C}$ and the evaluation of the mechanical properties was carried out after 1, 3, 7, 14 and 28 days of curing. The development of the compressive strength was evaluated using an automated hydraulic press (Controls $50-\mathrm{C} 70024)$ with capacity of $250 \mathrm{kN}$ and a loading

TABLE 1. Composition of analysed samples

\begin{tabular}{lrrrrrr}
\hline \multicolumn{7}{c}{ Weight \% } \\
\hline Compound & $\mathbf{s 1}$ & $\mathbf{s 2}$ & $\mathbf{s 3}$ & $\mathbf{s 4}$ & $\mathbf{s 5}$ & s6 \\
\hline $\mathbf{C}_{\mathbf{4}} \mathbf{A}_{\mathbf{3}} \hat{\mathbf{S}}$ & 85 & 85 & 80 & 80 & 75 & 75 \\
$\mathbf{C S \hat { H }}$ & 15 & 15 & 20 & 20 & 25 & 25 \\
Citric acid & 0 & 0.5 & 0 & 0.5 & 0 & 0.5
\end{tabular}

$\mathrm{CS}_{0.5}: \mathrm{CaSO}_{4} \cdot 1 / 2 \mathrm{H}_{2} \mathrm{O}$ 
rate of $350 \mathrm{~N} / \mathrm{s}$. Four cubes were tested, reporting the average for each time of curing. After the completion of the test, pieces were taken from each of the samples and immersed in methanol for $24 \mathrm{~h}$ to remove water and stop the hydration reactions. The hydration products and their evolution were identified by X-ray diffraction (XRD) and microstructures of the hydrated samples were observed by scanning electron microscopy (SEM). Samples for XRD characterization were taken out from the cubes crushed in the compressive tests and dried in a vacuum oven for $24 \mathrm{~h}$ at $35^{\circ} \mathrm{C}$; these were further ground to pass the sieve of 150 microns using a porcelain mortar. A Phillips PW 3040e diffractometer was used with $\mathrm{CuK} \alpha$ radiation (1.542 $\AA$ ) and a scanning range of $7-60^{\circ} 2 \theta$. The SEM and EDS analysis were performed using a Philips XL 30 SEM apparatus on fracture surfaces coated with graphite. Samples were analysed using the technique of backscattered electrons. Samples with additions of 15,20 and $25 \mathrm{wt} \%$ of hemihydrate were hydrated using a $0.4 \mathrm{w} / \mathrm{c}$ and studied by isothermal conduction calorimetry to follow the progress of the hydration reactions of cement pastes. The release rate of heat generated during the hydration was recorded as a function of time from the moment in which the water came in contact with the cement, obtaining curves under isothermal conditions. This technique can be used to study the rate of reactions at different temperatures, as well as for deciphering the role of chemical admixtures on the hydration and setting times (21). Generally, the plot of rate of heat evolution vs. time shows the occurrence of two maxima with the so-called induction period between them. The length of the latter is influenced by the additives that accelerate or retard the hydration, and consequently, the setting and hardening process (22). The calorimeter used was made based on the Forrester's design (23). Isothermal baths host the insulating cells containing the samples. A sample holder in the form of a copper ring is set inside the cell, the sample seats within the ring and on top of a thin copper plate that is in contact with the heat sensors (Peltier devices). The calorimeter has a data acquisition system to monitor and collect the signals over time.

\section{RESULTS AND DISCUSSION}

Figure 1 shows the graphs of compressive strength development of samples with $15 \mathrm{wt} \%$ hemihydrate, 0 and $0.5 \mathrm{wt} \%$ of citric acid and with w/c of 0.4 and 0.5 . It was noted that the strength was greatly influenced by the addition of the retarder. For samples with the retarder, the strength was very low at 1 day ( 9 and $6 \mathrm{MPa}$ using $\mathrm{w} / \mathrm{c}=0.4$ and 0.5 , respectively), compared with 34 and $30 \mathrm{MPa}$ from the samples without citric acid. After 3 days, the strength increased greatly for samples with citric

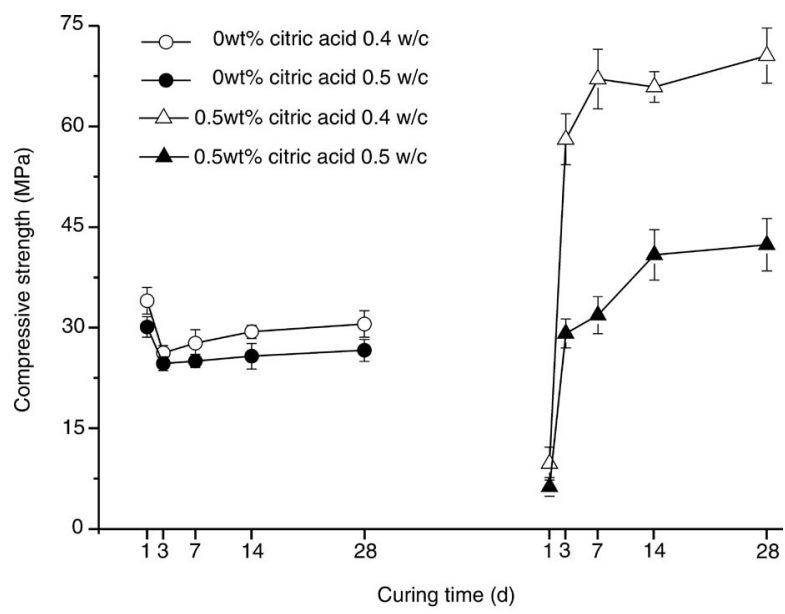

Figure 1. Compressive strength of samples with $15 \mathrm{wt} \%$ hemihydrate.

acid, reaching 70 and $42 \mathrm{MPa}$ for w/c of 0.4 and 0.5 , respectively after at 28 . The latter meant increases of 40 and $16 \mathrm{MPa}$ relative to 28 day values from the samples without retarder. The strength enhancement is attributed to a modification of the microstructures in the presence of the citric acid, which resulted in denser matrices of reaction products, as reviewed in subsequent sections; this seems to have also reduced the delayed ettringite formation, responsible for strength loss. Winnefeld and Barlag (24) indicated that in systems with low calcium sulphate additions, the ettringite formation is terminated shortly after setting; thus, expansive ettringite reactions cannot occur. On the contrary, the expansive behaviour of systems with ettringite/gypsum molar ratios of about 1:2 and beyond is related to the ongoing formation of ettringite in systems after setting.

Figure 2 shows the graphs of strength vs. time of samples with 20 and $25 \mathrm{wt}^{\%} \%$ of hemihydrate and $w / c$ of 0.4 and 0.5 , containing 0 and $0.5 \mathrm{wt} \%$ of citric acid. The behaviour of these samples was similar to that described for samples with $15 \mathrm{wt} \%$ hemihydrate, since there were relatively lower 1 day strength for samples with retarder and a further increase after 3 days. The 28 days strength reached by those samples with $0.5 \mathrm{wt} \%$ citric acid and $20 \mathrm{wt} \%$ hemihydrate were 60 and $46 \mathrm{MPa}$ for w/c of 0.4 and 0.5 , respectively; while for $25 \mathrm{wt} \%$ hemihydrate were 58 and $42 \mathrm{MPa}$, for w/c of 0.4 and 0.5 , respectively. The strength reduction for samples without retarder was caused by the delayed ettringite formation, which is a process of expansive nature that occurs after submerging the samples in water at 1 day of curing.

Figure 3 shows the curves of heat evolution rate vs time corresponding to samples with a) $15 \%$, b) $20 \%$ and c) $25 \mathrm{wt} \%$ of hemihydrate hydrated at $20{ }^{\circ} \mathrm{C}$ using a w/c of 0.4 . The heat release period 

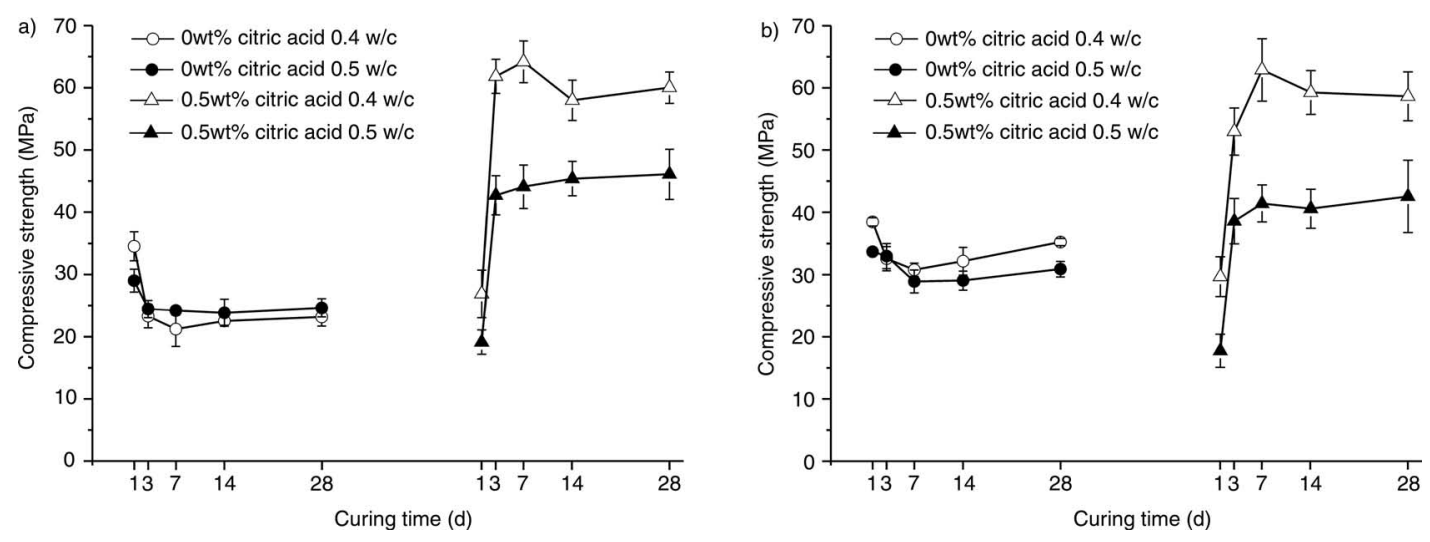

FIGURE 2. Compressive strength of samples with a) 20 and b) $25 \mathrm{wt} \%$ hemihydrate.
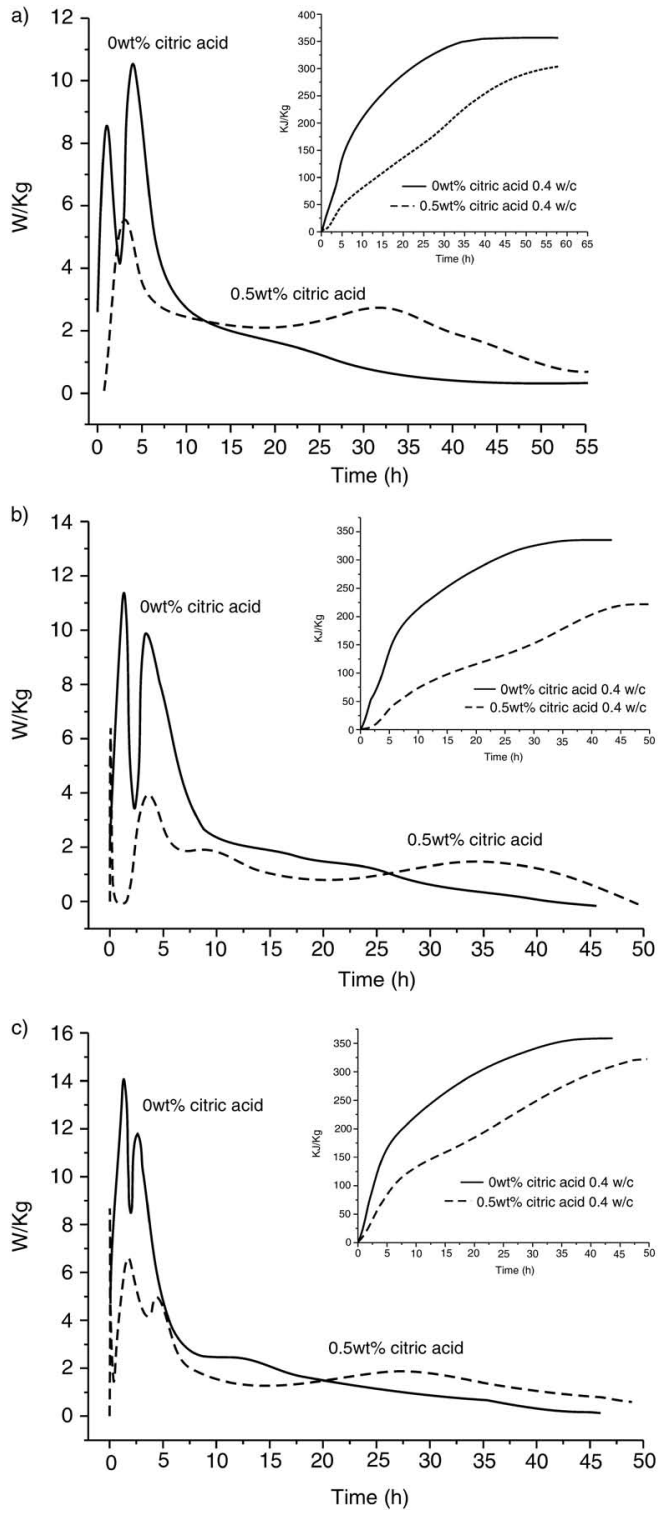

FIgURE 3. Heat evolution rate curves of samples with a) 15 , b) 20 and c) $25 \mathrm{wt} \%$ hemihydrate. was manifested by the appearance of 3 exothermic peaks from the instant at which the water came in contact with cement until it reaches a steady state during which the heat released is not detected by the technique. For the discussion, peaks were named as 1, 2 and 3 in order of appearance. As observed in figure $3 \mathrm{a}$ ), in the absence of citric acid, peak 1 was intense $(8.5 \mathrm{~W} / \mathrm{kg})$ and appeared after $1 \mathrm{~h}$ and was attributed mainly to the hydration of the hemihydrate, in agreement with (25); however, it is possible that ettringite formed simultaneously. It is noteworthy that peak 1 appeared more intense as the amount of hemihydrate increased in the cements. Peak 2 was more intense $(\sim 11 \mathrm{~W} / \mathrm{kg})$ and appeared at $\sim 4$ hours and is related mainly to ettringite formation. In the presence of citric acid, the maxima of peak 1 was shifted to $\sim 3 \mathrm{~h}$ and to $\sim 32 \mathrm{~h}$ for peak 2; at the same time, these peaks broadened and showed a decrease in the rate of heat release, reaching $5.5 \mathrm{~W} / \mathrm{kg}$ and $3 \mathrm{~W} / \mathrm{kg}$ for peak 1 and 2, respectively. The broadening indicates that the addition of the citric acid strongly retarded the hydration of the cement. These observations are confirmed by the curves of the total heat released, which after $50 \mathrm{~h}$ showed that the presence of $0.5 \mathrm{wt} \%$ citric acid decreased the total heat released from $\sim 350 \mathrm{~kJ} / \mathrm{kg}$ to $\sim 300 \mathrm{~kJ} / \mathrm{kg}$.

Figure 3 b) shows some differences relative to 3a). In the sample without citric acid, Peak 2, related to ettringite formation, reached $\sim 10 \mathrm{~W} / \mathrm{kg}$ and appeared slightly earlier than that of the sample with $15 \mathrm{wt} \%$ of gypsum, at $\sim 3.5 \mathrm{~h}$; also, a wide and weak exothermic manifestation, peak 3 , was noted from about 15 to 25 hours, suggesting the continuation of the reactions before reaching a steady state. In the presence of citric acid, peaks 1 and 2 appeared notably less intense, broadened and shifted to longer times; peak 1 shifted from $\sim 1.2$ to $3.5 \mathrm{~h}$ and reduced from 11 to $4 \mathrm{~W} / \mathrm{kg}$; while peak 2 was delayed by $\sim 5.5 \mathrm{~h}$ and reduced from 4 to $\sim 2 \mathrm{~W} / \mathrm{kg}$. With the admixture of citric acid, peak 3 was well defined and wide, reaching up to $\sim 1.5 \mathrm{~W} / \mathrm{kg}$ 
after 35; this peak is attributed to a continued ettringite formation. For the cement with $20 \%$ hemihydrate, the total heat release after $50 \mathrm{~h}$ decreased from $\sim 325 \mathrm{~kJ} / \mathrm{kg}$ to $\sim 275 \mathrm{~kJ} / \mathrm{kg}$ in the presence of $0.5 \mathrm{wt} \%$ of citric acid, which was consistent with the previous observation. The graphs of Figure $3 \mathrm{c}$ ) for cements with $25 \%$ hemihydrate showed similar features as those described for $20 \%$ hemihydrate. In the absence of citric acid, peak 2 related to ettringite formation $(\sim 11.5 \mathrm{~W} / \mathrm{kg})$ appeared at $2.7 \mathrm{~h}$, while with citric acid it shifted to $5 \mathrm{~h}$ reaching $\sim 5 \mathrm{~W} / \mathrm{kg}$; peak 3 , also related to ettringite formation appeared at $28 \mathrm{~h}(\sim 2 \mathrm{~W} / \mathrm{kg})$. The total heat release after $50 \mathrm{~h}$ decreased from $\sim 360 \mathrm{~kJ} / \mathrm{kg}$ to $\sim 325 \mathrm{~kJ} / \mathrm{kg}$ in the presence of $0.5 \mathrm{wt} \%$ of citric acid.

Figure 4 shows the XRD patterns corresponding to samples with 15,20 and $25 \mathrm{wt} \%$ of hemihydrate containing $0.5 \mathrm{wt} \%$ of citric acid and hydrated using a w/c of 0.4 at 1 (a) and 28 (b) days of curing. The results revealed that the main hydration product was the ettringite phase with its main peak located at $9.092 \theta$ degrees. The monosulphate phase was identified by a low intensity peak at $9.892 \theta$ degrees. After 28 days the intensity of the ettringite peaks increased, indicating that its formation continued after the cement had hardened. Besides ettringite and monosulphate, a high portion of non-reacted calcium sulphoaluminate was found, as well as traces of gypsum. The observations for those samples with $0 \mathrm{wt} \%$ of citric acid were fairly similar.

Figure 5 shows the microstructure of the sample containing $15 \mathrm{wt} \%$ of hemihydrate and $0.5 \mathrm{wt} \%$ of citric acid using a w/c of 0.4 at 1 and 28 days of curing. In the micrographs without retarder, Figures a) and b), two hydration products were observed.

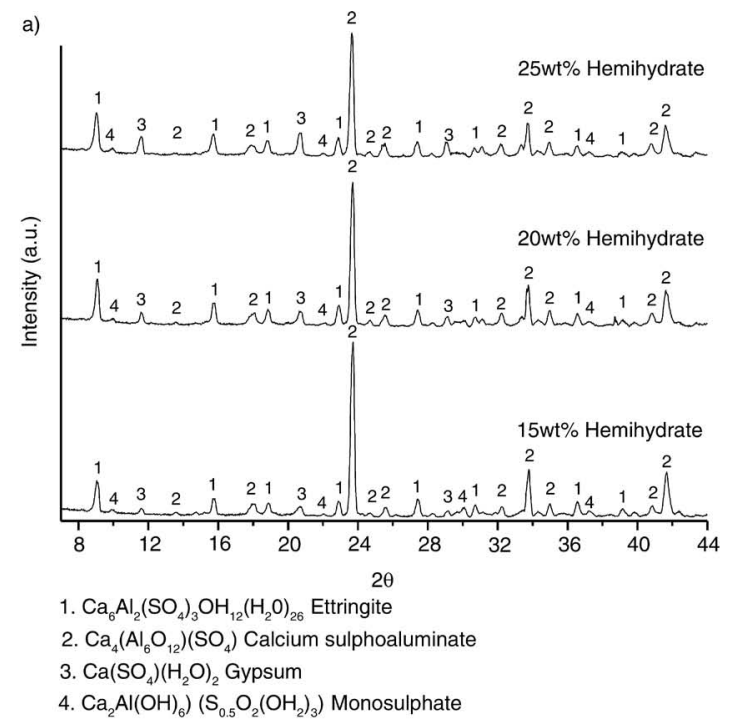

Microanalysis by EDS indicated that the needlelike morphology corresponds to the main hydration product phase, ettringite (Aft). The second phase exhibits morphology of hexagonal plates and correspond to phase monosulphate (AFm) $(26,27)$, which formed when there are not enough sulphates to form ettringite.

Figure 6 shows the microstructure of the sample containing $20 \mathrm{wt} \%$ of hemihydrate and $0.5 \mathrm{wt} \%$ of citric acid using a w/c of 0.4 at 1 and 28 days of curing. The micrographs of the samples without retarder, (a) and (b), clearly show the needlelike morphology of ettringite as the only hydration product, homogeneously distributed throughout the microstructure and with a length of approximately $10 \mu \mathrm{m}$. At 28 days (Figure 6 (c, d)) ettringite morphology shows thicker needles and there is a denser microstructure. The sample with citric acid exhibited a morphology of coarser and shorter needles than those from samples with no citric acid. This modification in morphology (Figure 6 (c, d)) favoured a better distribution of ettringita, reduced the expansion and led to enhancements of the compressive strength of the samples.

Figure 7 shows the microstructure of the sample containing $25 \mathrm{wt} \%$ of hemihydrate and $0.5 \mathrm{wt} \%$ of citric acid using a w/c of 0.4 at 1 and 28 days of curing. In the micrographs of samples without retarder, Figure $7(a, b)$, some gypsum crystals were observed even at 28 days of curing, which indicates that hydration reactions were not completed and ettringite may be formed at later stages. In the samples with of citric acid, the morphology of ettringite corresponded to small needles of less than $5 \mu \mathrm{m}$ in length, which appeared to have improved the densification of the microstructure.

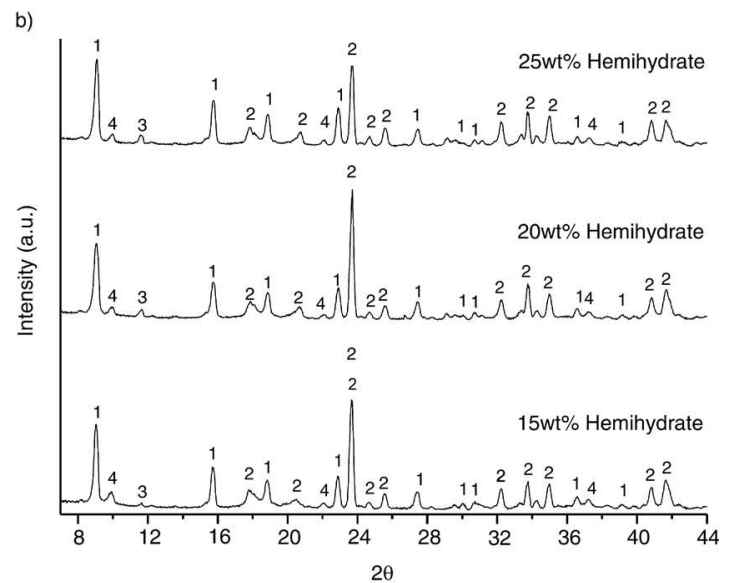

FIGURE 4. XRD patterns of samples with 15,20 and $25 \mathrm{wt} \%$ of hemihydrate containing $0.5 \mathrm{wt} \%$ citric acid hydrated at 1 a) and 28 b) days of curing using a w/c of 0.4 . 
a)
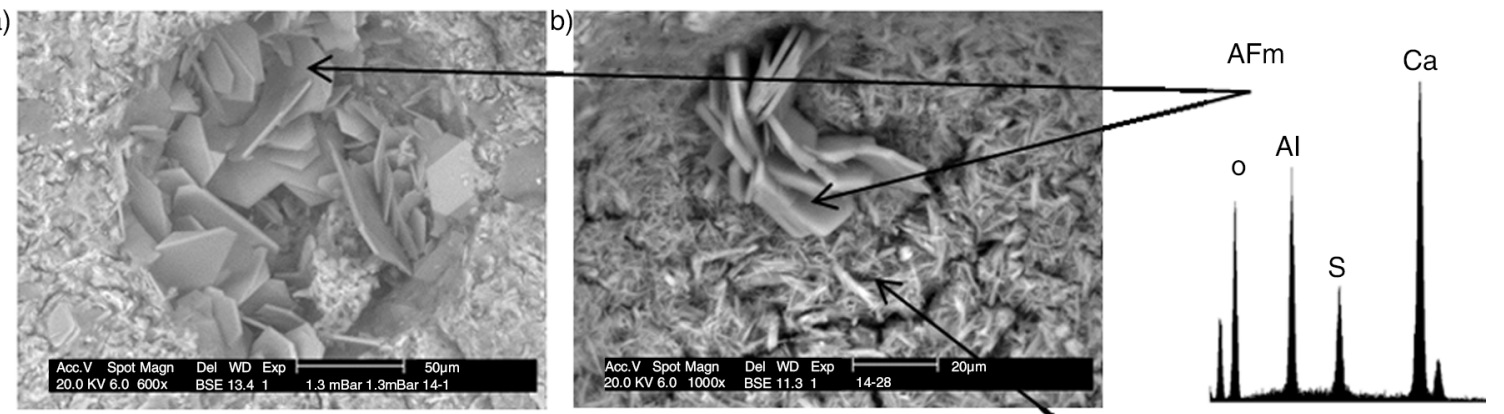

c)

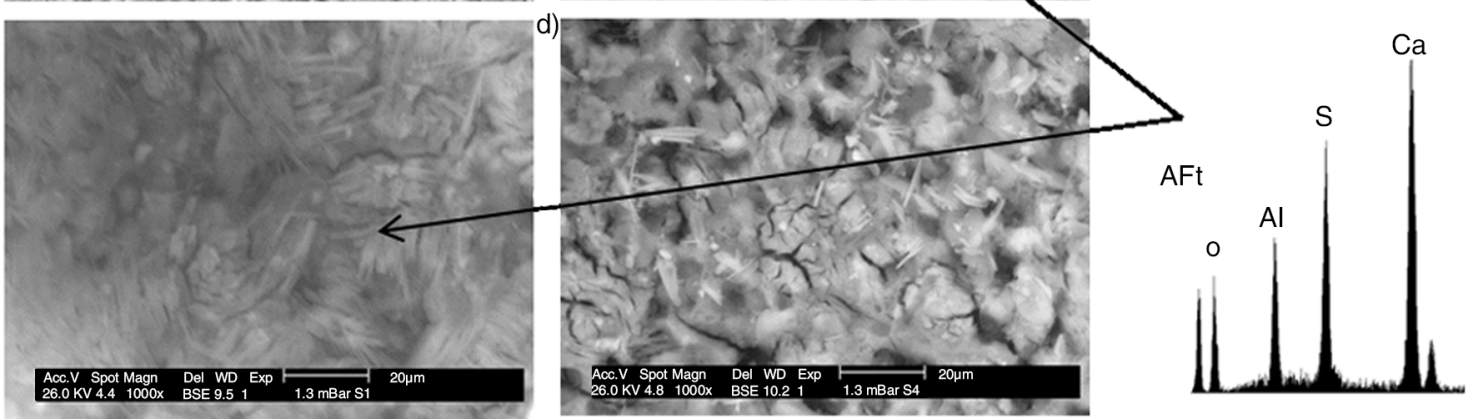

FIGURE 5. SEM images and EDS spectra of samples containing $15 \mathrm{wt} \%$ of hemihydrate at 1(a) and 28(b) days of curing and the same samples with $0.5 \mathrm{wt} \%$ of citric acid at $1(\mathrm{c})$ and $28(\mathrm{~d})$ days of curing.
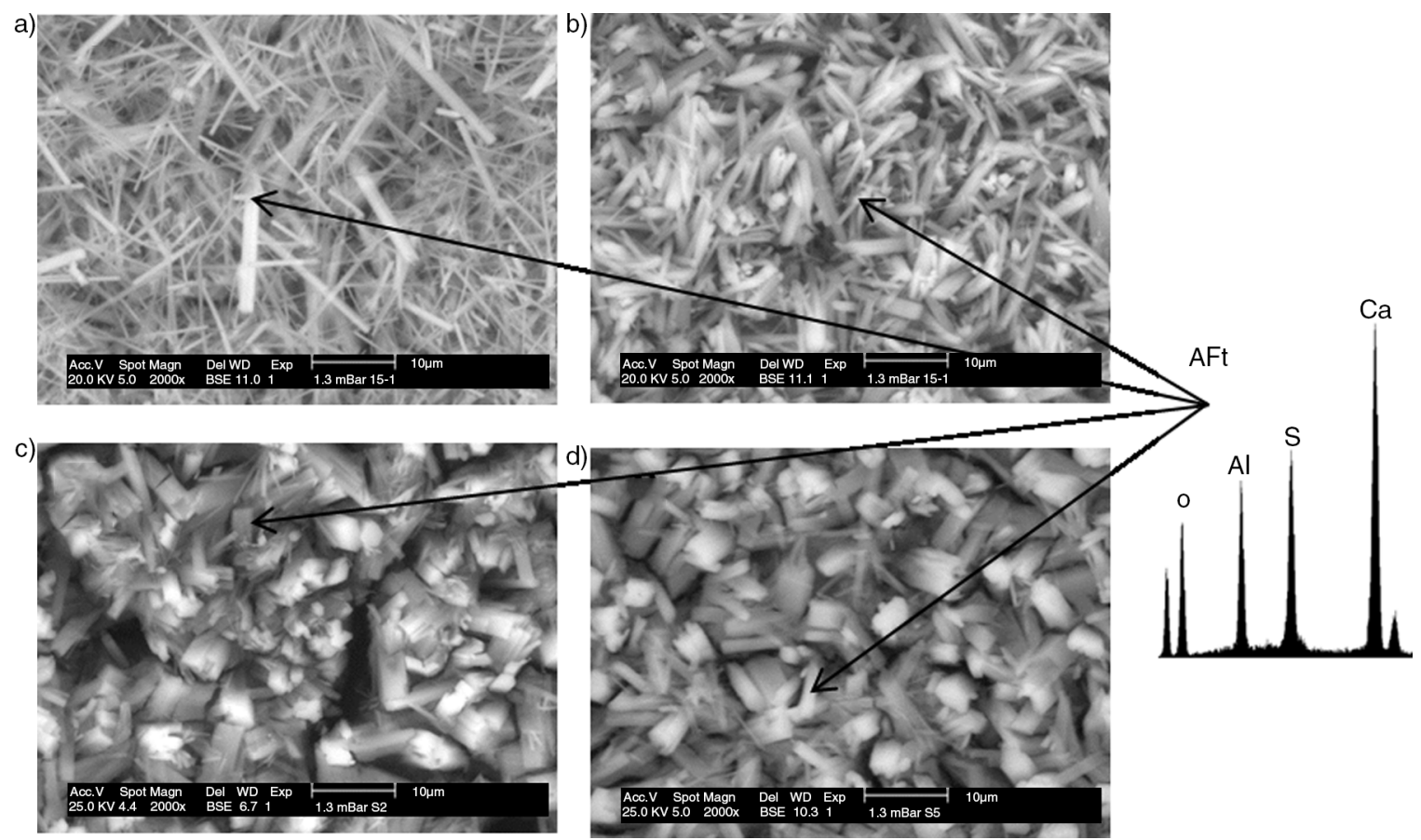

FIGURE 6. SEM images and EDS spectra of samples containing 20wt $\%$ of hemihydrate at 1 (a) and 28(b) days of curing and the same samples with $0.5 \mathrm{wt} \%$ of citric acid at 1 (c) and 28(d) days of curing.

\section{CONCLUSIONS}

The compressive strength of the calcium sulphoaluminate cements was improved by the addition of citric acid. The maximum compressive strength
(70 MPa) was observed in the samples with $15 \mathrm{wt} \%$ of hemihydrate and $0.5 \mathrm{wt} \%$ of citric acid with $\mathrm{w} / \mathrm{c}=0.4$, which is $40 \mathrm{MPa}$ greater than that of the sample without retarder. The maximum strength reached for the samples containing $20 \mathrm{wt} \%$ hemihydrate and 

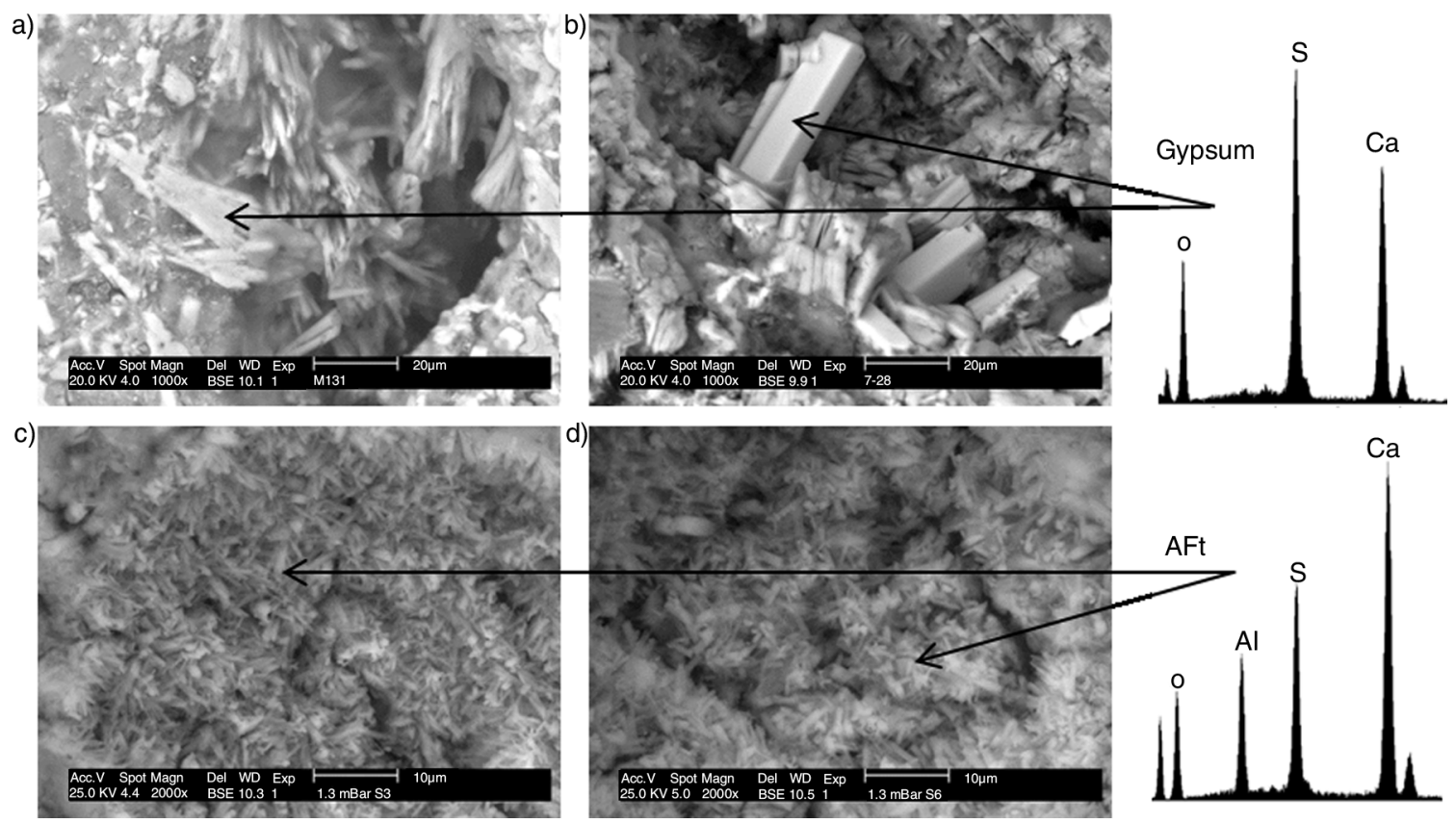

FIGURE 7. SEM images and EDS spectra of samples containing $25 \mathrm{wt} \%$ of hemihydrate at 1 (a) and 28 (b) days of curing and the same samples with $0.5 \mathrm{wt} \%$ of citric acid at 1 (c) and $28(\mathrm{~d})$ days of curing.

$0.5 \mathrm{wt} \%$ citric acid with $\mathrm{w} / \mathrm{c}=0.4$ was $60 \mathrm{MPa}$ and samples with $25 \mathrm{wt} \%$ hemihydrate and $0.5 \mathrm{wt} \%$ citric acid reached $58 \mathrm{MPa}$ with w/c $=0.4$. The curves of heat evolution rate indicate that the addition of citric acid strongly retarded the hydration of the cement and the total heat released. Analyses by XRD, SEM and EDS showed ettringite as the main hydration product although traces of monosuphate phase were also found. The addition of citric acid increased the setting time, modified the morphology of the ettringite needles, changed the microstructural configuration and prevented the decreasing in compressive strength of the samples caused by delayed ettringite formation.

\section{REFERENCES}

1. Sharp, J.H.; Lawrence, C.D.; Yang, R. (1999) Calcium sulphoaluminate cements - low-energy cements, special cements or what? Adv. Cem. Res., 11 [1], 3-13. http://dx.doi. org/10.1680/adcr.1999.11.1.3.

2. Propescu, C.D.; Mountean, M.; Sharp, J.H. (2003) Industrial trial production of low energy belite cement. Cem. Concr. Comp., 25 [7], 689-693. http://dx.doi.org/ 10.1016/S0958-9465(02)00097-5.

3. Juenger, M.C.G.; Winnefeld, F.; Provis, J.L.; Ideker, J.H. (2011) Advances in alternative cementitious binders. Cem. Concr. Res., 41 [12], 1232-1243. http://dx.doi.org/10.1016/j. cemconres.2010.11.012.

4. Gartner, E. (2004) Industrially interesting approaches to "low-CO $\mathrm{CO}_{2}$ cements. Cem. Concr. Res., Vol. 34 [9], 14911496. http://dx.doi.org/10.1016/j.cemconres.2004.01.021.

5. Odler, I. (2000) Special inorganic cements, Ed. Library Binding, Great Britain

6. Kasselouri, V.; Tsakiridis, P.; Malami, Ch.; Georgali, B.; Alexandridou, C. (1995) A study on the hydration products of non-expansive calcium sulfoaluminate cement.
Cem. Concr. Res., 25 [8], 1726-1736. http://dx.doi.org/ 10.1016/0008-8846(95)00168-9.

7. Metha, P.K.; Klein, A. (1965) Formation of Ettringite by Hydration of a System Containing an Anhydrous Calcium Sulfoaluminate. J. Am. Cer. Soc., 48 [8], 435-436. http:// dx.doi.org/10.1111/j.1151-2916.1965.tb14786.x

8. Puertas, F.; Blanco, M.T.; Gimenez-Molina, S. (1995) Kinetics of the thermal decomposition of $\mathrm{C}_{4} \mathrm{~A}_{3} \mathrm{~S}$ in air. Cem. Concr. Res. 25 [3], 572-580. http://dx.doi.org/10.1016/ 0008-8846(95)00046-F.

9. Glasser, F.P.; Zhang, L. (2001) High-performance cement matrices based on calcium sulfoaluminate-belite compositions. Cem. Concr. Res., 31 [12], 1881-1886. http://dx.doi. org/10.1016/S0008-8846(01)00649-4.

10. Arjunan, P.; Silsbee, M.R.; Roy, D.M. (1999) Sulfoaluminatebelite cement from low-calcium fly ash and sulfur rich and other industrial by-products. Cem. Concr. Res., 29 [8], 13051309. http://dx.doi.org/10.1016/S0008-8846(99)00072-1.

11. Perá, J;; Ambroise, J. (2004) New applications of calcium sulfoaluminate cement. Cem. Concr. Res., Vol. 34 [4], 671676. http://dx.doi.org/10.1016/j.cemconres.2003.10.019.

12. Sahu, S.; Havlica, J.; Tomková, V.; Majling, J. (1991) Hydration behaviour of sulphoaluminate belite cement in the presence of various calcium sulphates. Thermochimica Acta, 175 [1], 45-52. http://dx.doi.org/10.1016/0040-6031 (91)80244-D.

13. Winnefeld, F.; Lothenbach, B. (2010) Hydration of calcium sulphoaluminate cements - experimental findings and thermodinamic modeling. Cem. Concr. Res., 40 [1], 1239-1247. http://dx.doi.org/10.1016/j.cemconres.2009.08.014.

14. Escalante-Garcia, J.I.; Rios-Escobar, M.; Gorokhovsky, A.; Fuentes, A.F. (2008) Fluorgypsum binders with OPC and PFA additions, strength and reactivity as a function of component proportioning and temperatura, Cem. Concr. Comp., 30 [2] 88-96. http://dx.doi.org/10.1016/j. cemconcomp.2007.05.015.

15. Lorprayon, V.; Rossington, D.R. (1981) Early hydration of cement constituents with organic admixtures. Cem. Concr. Res., 11 [2], 267-277. http://dx.doi.org/10.1016/ 0008-8846(81)90068-5.

16. Hewlett, P.C. (2004) Lea's Chemistry of Cement and Concrete 4th Edition, Elsevier, (2004). 
17. Tinnea, J.; Young, J.F. (1977) Influence of citric acid on reactions in the system $3 \mathrm{CaO}-\mathrm{Al}_{2} \mathrm{O}_{3}-\mathrm{CaSO}_{4} \cdot \mathrm{H}_{2} \mathrm{O}-\mathrm{CaO}-\mathrm{H}_{2} \mathrm{O}$ J. Am. Ceram. Soc., 60 [9], 387-389. http://dx.doi.org/ 10.1111/j.1151-2916.1977.tb15518.x.

18. Singh, N.B.; Shing, A.K.; Shing, S.P. (1990) Hydration study of the system $\mathrm{Ca}_{3} \mathrm{Al}_{2} \mathrm{O}_{6}-\mathrm{CaSO}_{4} \cdot 2 \mathrm{H}_{2} \mathrm{O}-\mathrm{Ca}(\mathrm{OH})_{2}-\mathrm{H}_{2} \mathrm{O}$ with and without citric acid. J. Am. Ceram. Soc., 73 [10], 30633068. http://dx.doi.org/10.1111/j.1151-2916.1990.tb06717.x.

19. Möschner, G; Lothenbach, B; Figi, R. Kretschmar, R. (2009) Influence of citric acid on the hydration of Portland cement. Cem. Concr. Res., 39 [4], 275-282. http://dx.doi.org/ 10.1016/j.cemconres.2009.01.005.

20. ASTM C-204, Fineness of Hydraulic Cement by Air Permeability Apparatus, 1995 Annual Book of ASTM Standars. Section 4. Construction. Volume 04.01. Cement, Lime, Gypsum.

21. Ramachandran, V.R.; Beaudoin, J.J. (2001) Handbook of Analytical Techniques in Concrete Science and Technologies. Noyes Publications, (2001).

22. Kurdowsky, W.; Nokun-Wzcelik, W. (1995) Calorimetric Studies Of Special Cements. J. Therm. Anal., 45 [10], 923930. http://dx.doi.org/10.1007/BF02547459.
23. Escalante, J.I.; Sharp, J.H. (2000) The effect of temperature on early hydration of Portland cement and blended cements. Adv. Cem. Res., 12 [3], 121-130. http://dx.doi.org/ 10.1680/adcr.2000.12.3.121.

24. Winnefeld, F.; Barlag, S. (2010) Calorimetric and thermogavimetric study on the influence of calcium sulfate on the hydration of ye'elimite. J. Therm. Anal. Calorim., 101 [3], 949-957. http://dx.doi.org/10.1007/s10973-009-0582-6.

25. Magallanes-Rivera, R.X.; Escalante-Garcia, J.I.; Gorokhovsky, A. (2009) Hydration reactions and microstructural characteristics of hemihydrate with citric and malic acid, Constr Build Mater, 23 [3] 1298-1305. http:// dx.doi.org/10.1016/j.conbuildmat.2008.07.022.

26. Quennoz, A.; Scrivener, K.L. (2012) Hydration of C3Agypsum systems. Cem. Concr. Res., 42 [7], 1032-1041. http://dx.doi.org/10.1016/j.cemconres.2012.04.005.

27. Motzet, H.; Pöllmann, H. (1999) Synthesis and characterisation of sulfite-containing AFm phases in the system $\mathrm{CaO}-\mathrm{Al}_{2} \mathrm{O}_{3}-\mathrm{SO}_{2}-\mathrm{H}_{2} \mathrm{O}$. Cem. Concr. Res., 29 [7], 1005-1011. http://dx.doi.org/10.1016/S0008-8846(99)00082-4. 